\title{
Forty-three percent of Eligible Rural Families Can Claim a Larger Credit with EITC Expansion
}

\author{
MARYBETH J. MAT T INGLY
}

\section{Overview}

Rural families are poised to benefit from recent expansions to the federal Earned Income Tax Credit (EITC). These expansions provide important assistance to married couples and to larger families. According to the U.S. Census Bureau, there are over 6.5 million families with children residing in rural America. ${ }^{1}$ Thirty-nine percent of these families are eligible for the EITC and can now claim an average credit of $\$ 2,638$, representing an average annual increase of $\$ 115$. $^{2}$ This brief examines (1) the structure of the federal EITC prior to the American Recovery and Reinvestment Act (ARRA), or "stimulus plan"; (2) changes made by the ARRA; (3) the financial impact these changes have on families, with particular focus on rural America and regional differences; and (4) how additional expansions of the federal EITC could further aid working, low-income individuals and families.

\section{About the Earned Income Tax Credit}

The federal Earned Income Tax Credit (EITC) began in 1975 and was initially conceived as a program to support the working poor and offset the regressivity of payroll taxes. It became permanent in 1978 and was expanded several times, including during the 1986 tax overhaul and again in 1990 and 1993. President Clinton's 1993 expansion doubled the size of the EITC and, for the first time, made a small credit available to childless workers and noncustodial working parents. ${ }^{3}$ The EITC is fully refundable so that all eligible families receive the full amount for which they are eligible, first as a tax credit, and after taxes are covered, as a refund.

The EITC is one of the most effective programs for lifting working families out of poverty because it supplements the wages or lessens the tax burden of working families with low to moderate income. ${ }^{4}$ The EITC has a greater impact than any other program, having lifted more than 4 million people out of poverty in 2005 , including 2.6 million children. ${ }^{5}$ Additionally, the EITC promotes participation in the labor force, particularly among single mothers, and may help reduce economic inequality. ${ }^{6}$ Finally, there is a "community effect" since recipients often spend their EITC money in the low-income places where they live.

EITC eligibility and benefit levels are determined by marital status and family size, as shown in Figure 1 and discussed in Box 1. The shaded portions represent families of different sizes and the dashed lines show differences for married couples. In general, the EITC does a much better job assisting low-income families with resident children than it does assisting workers without qualifying children. Further, the EITC has not historically provided greater relief to large families (those with more than two children), even though such families are very likely to be poor even when working. ${ }^{8}$ Also, inherent in the EITC is a "marriage penalty" when both spouses are employed: A couple's EITC eligibility is based upon joint earnings, with the couple's eligibility range not being much higher than that of a single tax filer. ${ }^{9}$ 
Figure 1. The federal EARned Income Credit In taX year 2009

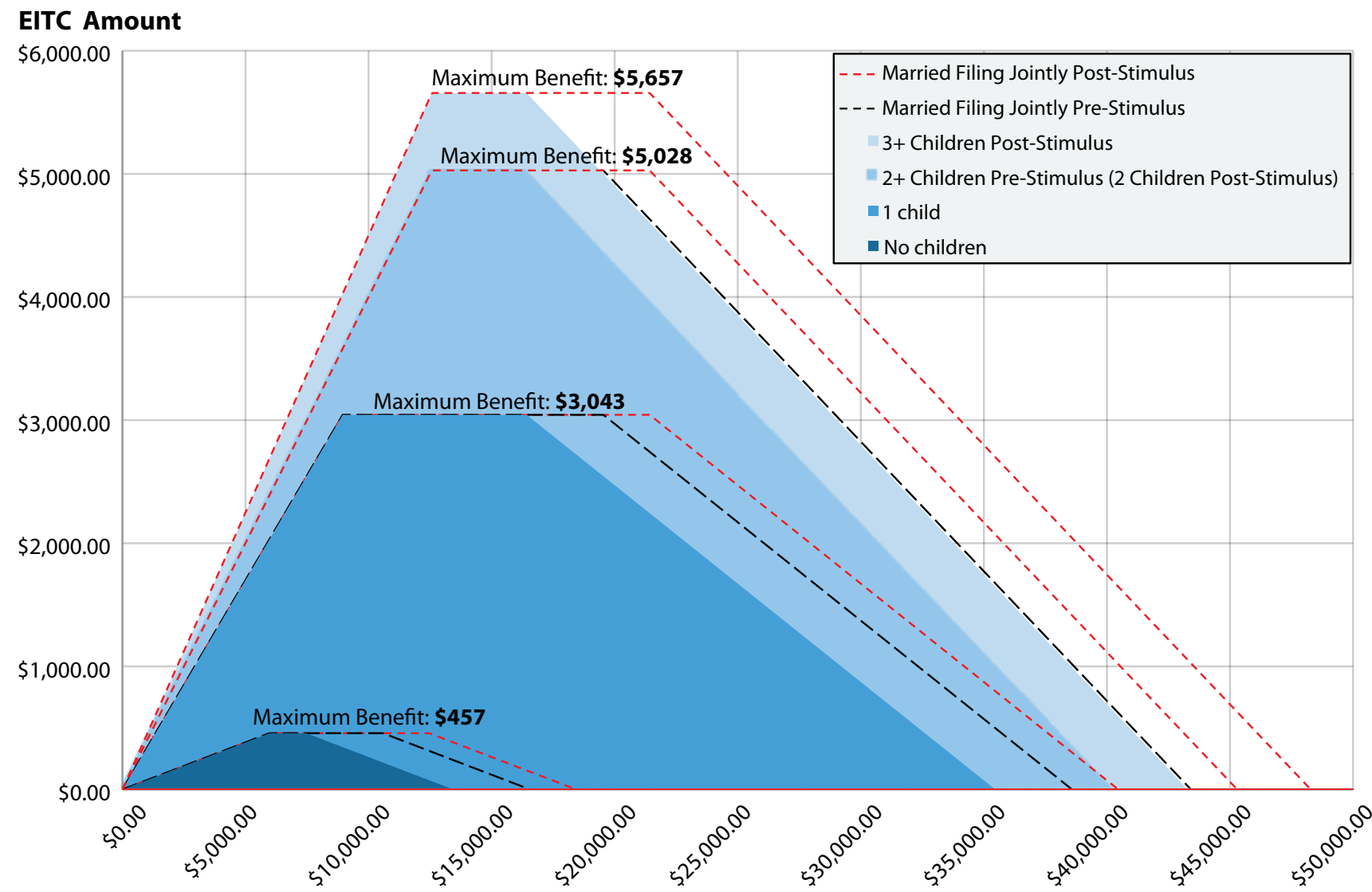

Annual Income

Box 1: Details of the federal EARned Income Tax Credit (PRe-STimulus)

Figure 1 shows that, prior to the ARRA, the EITC for tax year 2009 would have been administered as follows:

Childless workers (including noncustodial parents) aged 25 to 64 were eligible for a credit equal to 7.65 percent of their earnings (this is the gentlest slope on the left-hand side of Figure 1) up to a maximum credit of $\$ 457$ (the lowest plateau in Figure 1). When earnings or income exceeded $\$ 7,470$ ( $\$ 10,590$ for married couples as shown by the black dashed line), the credit phased out at a rate of 7.65 percent of every dollar over the $\$ 7,470$ ( $\$ 10,590$ for married couples) threshold (the gentlest right hand slope in Figure 1). Childless workers earning more than $\$ 13,444$ were ineligible for the EITC, as were childless married couples with earned income greater than $\$ 16,564$.

Workers with one qualifying child were eligible for a credit of 34 percent of their earnings up to a maximum credit of $\$ 3,043$. Phase-out, at the rate of 15.98 percent, began at $\$ 16,420$ ( $\$ 19,540$ for married couples). Those with earnings over $\$ 35,463$ ( $\$ 38,583$ for married couples) could not claim the EITC.

Those with two or more qualifying children were eligible for a credit of 40 percent of their earnings up to a maximum credit of $\$ 5,028$. The credit phased out at the rate of 21.06 percent of each dollar above $\$ 16,420$ ( $\$ 19,540$ for married couples). At an earnings level of $\$ 40,295$, individuals ( $\$ 43,415$ for married couples) became ineligible for the EITC.

Additionally, tax filers (individuals or couples) with more than $\$ 3,100$ of investment income did not qualify for the EITC. ${ }^{10}$ 


\section{Larger Families and Married Couples Benefit from Recent Expansion of the EITC}

The ARRA made two important changes to the EITC that will provide an additional estimated $\$ 3.4$ billion in benefits to hardworking families. These changes are available for the next two years but are set to expire in 2011. President Obama proposes making these changes permanent in his 2009 budget proposal. ${ }^{11}$ This would be an important step to making work pay for hardworking American families. The changes offer important relief to larger families and substantially reduce the marriage penalty:

1. The needs of larger families (those with 3 or more children) are addressed by increasing the rate at which they accrue EITC benefits and slightly raising the maximum credit amount. ${ }^{12}$

2. The marriage penalty was reduced in the ARRA by increasing the income threshold at which the EITC begins to phase out for married couples. ${ }^{13}$ Two-earner married couples face a "penalty" when claiming the EITC in that they are required to report joint income, and then typically receive a smaller credit compared to what they could claim if they were not married.

To summarize, the changes made to the federal EITC in the stimulus plan raise income thresholds for married filers and increase the benefit for large families. ${ }^{14}$

\section{The EITC from a Regional Perspective}

The EITC plays an especially important role in raising the income of those with custodial children. Table 1 shows the 2009 EITC eligibility distribution and refund amounts both before and after passage of the ARRA, broken down by region and place for all families with qualifying children. ${ }^{15}$ Several things are clear:

- An estimated 39 percent of rural families with children are now eligible for the EITC; 40 percent of central city families are eligible and approximately 28 percent of suburban families can claim the credit. Eligibility is virtually unchanged by the passage of the ARRAjust over 1 percent of families with children are newly eligible for the EITC.

- 44 percent of families who can claim the EITC are eligible for increased benefits. This ranges from a low of 36 percent in the suburban Northeast to a high of more than 50 percent in Western suburban and central city communities.

- Rural families with children eligible for the EITC can now claim an average credit of $\$ 2,638$, which represents an average annual increase of $\$ 115$. The smallest increase for rural families is in the Midwest (\$97) and the largest is in the Northeast (\$138). For eligible suburban families, the average credit is now $\$ 2,617$, an average increase of $\$ 147$. The largest increase among suburban tax filers is in the West (\$177) and the smallest is in the Northeast (\$107). Central city dwellers with qualifying children eligible for the EITC now receive an average credit of $\$ 2,798$, an increase of $\$ 178$, on average, with the largest average increase to Southern and Western central city residents (\$196 and \$195, respectively) and the smallest to those in the Midwest and Northeast (\$143 and \$144, respectively).

- The expansion of the EITC will provide an additional $\$ 3.4$ billion to America's families-an estimated \$566 million will go to those in rural America, almost \$1.3 billion to suburban families, and over $\$ 1.1$ billion to families with children residing in central cities. (The remaining dollars will go to families in places not identified in Census data.)

These differences are driven by the demographic characteristics of the regions, as all of the increases accrue to large families and families headed by married couples (large families headed by married couples doubly benefit). Table 2 shows the distribution of families affected by family composition and place, and illustrates eligibility and average benefits both prior to the ARRA and after its signing into law. Note that married couples without children are included in this table to show how the expansion affects them. 
TABle 1. 2009 EARned InCome TAX Credit Eligibility AND AVERAge Benefit AMOUNTS FOR FAMILIES With CHILdren before and after the passage of The American Recovery and Reinvestment Act

\begin{tabular}{|c|c|c|c|c|c|c|c|c|}
\hline & \multicolumn{2}{|c|}{ PRIOR TO STIMULUS PLAN } & \multicolumn{6}{|c|}{ AFTER THE STIMULUS PLAN } \\
\hline & $\begin{array}{l}\text { Families } \\
\text { Eligible for } \\
\text { EITC }\end{array}$ & $\begin{array}{c}\text { Of Eligibles, } \\
\text { Average EITC } \\
\text { Amount }\end{array}$ & $\begin{array}{c}\text { Number of } \\
\text { Families } \\
\text { Eligible } \\
\text { for ElTC } \\
\text { (Thousands) }\end{array}$ & $\begin{array}{l}\text { Families } \\
\text { Eligible for } \\
\text { EITC }\end{array}$ & $\begin{array}{c}\text { Of Eligibles, } \\
\text { Average EITC } \\
\text { Amount }\end{array}$ & $\begin{array}{c}\text { Of Eligibles, } \\
\text { Percent with } \\
\text { Increased } \\
\text { Benefit }\end{array}$ & $\begin{array}{l}\text { Of Eligibles, } \\
\text { Average } \\
\text { Increased } \\
\text { Benefit }\end{array}$ & $\begin{array}{c}\text { Total Increase } \\
\text { in ElTC } \\
\text { (Millions) }\end{array}$ \\
\hline U.S. Total ${ }^{1}$ & $32 \%$ & $\$ 2,510$ & 14,050 & $34 \%$ & $\$ 2,660$ & $44 \%$ & $\$ 150$ & $\$ 3,433$ \\
\hline Northeast ${ }^{2}$ & $29 \%$ & $\$ 2,424$ & 2,187 & $30 \%$ & $\$ 2,551$ & $38 \%$ & $\$ 127$ & $\$ 443$ \\
\hline Midwest $^{3}$ & $30 \%$ & $\$ 2,473$ & 2,894 & $32 \%$ & $\$ 2,608$ & $42 \%$ & $\$ 135$ & $\$ 674$ \\
\hline South ${ }^{4}$ & $35 \%$ & $\$ 2,529$ & 5,572 & $36 \%$ & $\$ 2,672$ & $45 \%$ & $\$ 143$ & $\$ 1,337$ \\
\hline West $^{5}$ & $33 \%$ & $\$ 2,567$ & 3,395 & $34 \%$ & $\$ 2,755$ & $51 \%$ & $\$ 188$ & $\$ 979$ \\
\hline Rural Total & $38 \%$ & $\$ 2,523$ & 2,504 & $39 \%$ & $\$ 2,638$ & $43 \%$ & $\$ 115$ & $\$ 566$ \\
\hline Northeast & $34 \%$ & $\$ 2,289$ & 273 & $35 \%$ & $\$ 2,427$ & $40 \%$ & $\$ 138$ & $\$ 58$ \\
\hline Midwest & $36 \%$ & $\$ 2,449$ & 749 & $38 \%$ & $\$ 2,546$ & $42 \%$ & $\$ 97$ & $\$ 173$ \\
\hline South & $41 \%$ & $\$ 2,623$ & 1,214 & $42 \%$ & $\$ 2,743$ & $43 \%$ & $\$ 120$ & $\$ 267$ \\
\hline West & $34 \%$ & $\$ 2,516$ & 268 & $36 \%$ & $\$ 2,639$ & $45 \%$ & $\$ 123$ & $\$ 68$ \\
\hline Suburban Total & $27 \%$ & $\$ 2,470$ & 5,054 & $28 \%$ & $\$ 2,617$ & $45 \%$ & $\$ 147$ & $\$ 1,266$ \\
\hline Northeast & $21 \%$ & $\$ 2,312$ & 813 & $22 \%$ & $\$ 2,420$ & $36 \%$ & $\$ 107$ & $\$ 151$ \\
\hline Midwest & $25 \%$ & $\$ 2,476$ & 994 & $26 \%$ & $\$ 2,643$ & $43 \%$ & $\$ 167$ & $\$ 254$ \\
\hline South & $29 \%$ & $\$ 2,456$ & 1,979 & $30 \%$ & $\$ 2,584$ & $45 \%$ & $\$ 127$ & $\$ 477$ \\
\hline West & $29 \%$ & $\$ 2,587$ & 1,268 & $31 \%$ & $\$ 2,774$ & $52 \%$ & $\$ 177$ & $\$ 383$ \\
\hline Central City Total & $39 \%$ & $\$ 2,620$ & 4,405 & $40 \%$ & $\$ 2,798$ & $47 \%$ & $\$ 178$ & $\$ 1,123$ \\
\hline Northeast & $42 \%$ & $\$ 2,593$ & 814 & $43 \%$ & $\$ 2,736$ & $39 \%$ & $\$ 144$ & $\$ 171$ \\
\hline Midwest & $35 \%$ & $\$ 2,657$ & 674 & $36 \%$ & $\$ 2,800$ & $44 \%$ & $\$ 143$ & $\$ 156$ \\
\hline South & $40 \%$ & $\$ 2,597$ & 1,492 & $41 \%$ & $\$ 2,794$ & $48 \%$ & $\$ 196$ & $\$ 397$ \\
\hline West & $37 \%$ & $\$ 2,641$ & 1,425 & $39 \%$ & $\$ 2,836$ & $51 \%$ & $\$ 195$ & $\$ 399$ \\
\hline
\end{tabular}

Source: Current Population Survey 2008 Annual Social and Economic Supplement

1 Includes places not identified by the Census Bureau.

2 Includes Maine, New Hampshire, Vermont, Massachusetts, Rhode Island, Connecticut, New York, New Jersey, and Pennsylvania.

3 Includes Ohio, Indiana, Illinois, Michigan, Wisconsin, Minnesota, Iowa, Missouri, North Dakota, South Dakota, Nebraska, and Kansas.

\section{Demographics of Those Affected by EITC Expansion}

EITC-eligible married couples with fewer than three children will see modest average increases in their benefit amount: \$34 annually for those without qualifying children and \$104 annually for those with one or two qualifying children. However, the substantial effect of the tax changes is on the benefit amount for larger families.

While eligibility rates increase for some types of families, the big story is in increased benefits. All families with
4 Includes Delaware, Maryland, District of Columbia, Virginia, West Virginia, North Carolina, South Carolina, Georgia, Florida, Kentucky, Tennessee, Alabama, Mississippi, Arkansas, Louisiana, Oklahoma, and Texas.

5 Includes Montana, Idaho, Wyoming, Colorado, New Mexico, Arizona, Utah, Nevada, Washington, Oregon, California, Alaska, and Hawaii.

three or more children are eligible for a higher tax credit. The average increase is $\$ 514$ for eligible married couples with three or more children and $\$ 405$ for single filers with three or more children. When looking at the demographic distribution of families with three or more children, families headed by married couples in rural and suburban areas will receive a smaller refund than the average, due to annual income. Families headed by a single parent in suburban areas will see a larger refund than the average due to income amount, as will families headed by married couples in central cities. 


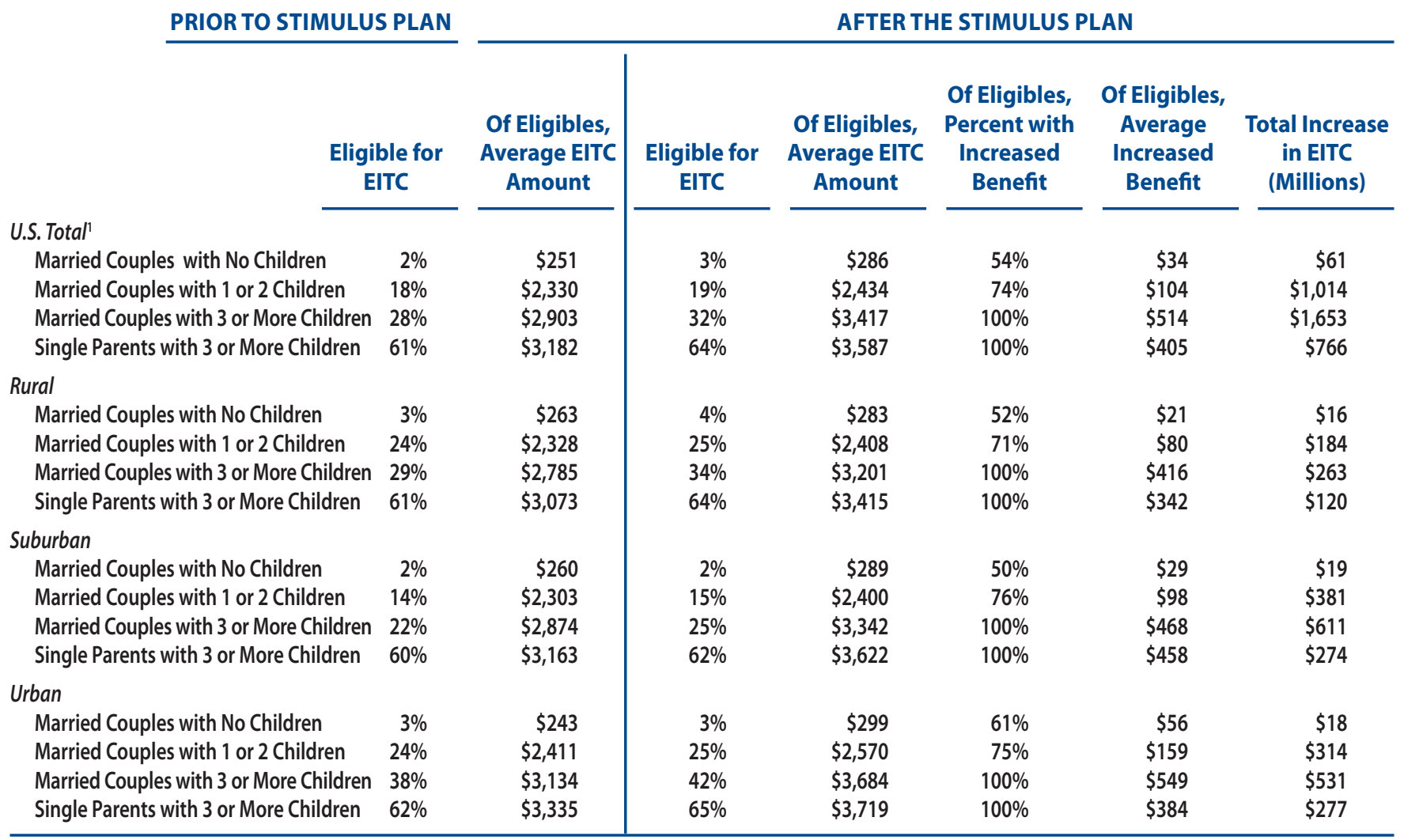

1 Includes places not identified by the Census Bureau.

Source: Current Population Survey 2008 Annual Social and Economic Supplement

\section{Increasing the Effectiveness of the Credit}

While the changes to the EITC represent an important step toward "making work pay" for America's families, there are additional steps that need to be considered. Of primary importance is expanding EITC benefits to childless and noncustodial parent workers. Many of these individuals are struggling to make ends meet and often have financial responsibilities for noncustodial children. Additionally, labor force participation among lesser-skilled men (particularly among men of color) is declining; the EITC could provide an incentive for work. ${ }^{16}$

Recognizing the needs of childless workers and noncustodial parents, and expanding the EITC to better meet them, is an important tool for poverty prevention, especially given that current policy taxes poor, childless workers "deeper into poverty." ${ }^{17}$ Proposals for expanding this credit include removing the age requirement so that younger workers are eligible if they are not attending school full time, and expanding the credit to both cover more workers and provide greater benefits. ${ }^{18}$

Although the expansion of the EITC did reduce the marriage penalty for dual-earner, low-income couples, there can still be a substantial penalty when both spouses are working. For example, consider a couple with two children, where each partner earns an annual salary of $\$ 15,000$. If they are unmarried and one person claims both children, the EITC both before and after the expansion is $\$ 5,028$. Under the 2009 rules prior to the ARRA, if this couple is married, the maximum EITC was $\$ 2,825$. With the expansion, this is increased by $\$ 396$ to $\$ 3,221$, but still falls short of the credit that would have been received if the couple was unmarried, by a staggering $\$ 1,807$.

An important step in reducing poverty, especially childhood poverty, may be to completely remove the marriage penalty. Gordon Berlin suggests allowing primary-earners to 
claim the child-based EITC and allowing a separate EITC for their low-earning spouses, perhaps with work hours requirements and total family income caps. ${ }^{19}$ Another proposal from the Center for American Progress and the Brookings Institution is to disregard half the earnings of the lower earning spouse if doing so increases the EITC for the family. ${ }^{20}$ In the hypothetical family unit discussed above, the EITC would be based upon joint earnings of $\$ 22,500$ and would be $\$ 4,801$; the marriage penalty in this scenario would be reduced to $\$ 227$.

\section{Data Used in this Brief}

This analysis is based upon estimates from the 2008 Annual Social and Economic Supplement to the Current Population Survey (CPS). This is a family-level analysis based on family reference persons, with information about their spouse and children, where applicable. Note that these estimates based on CPS data do not include all possible nuanced family tax situations. The analyses assume married couples with a spouse present file joint income tax returns and assume only one tax filing unit per family. The CPS does not collect detailed tax information, thus estimates are based on reported earnings, investment income, and CPS calculated adjusted gross income. All of these values were collected for tax year 2007 and have been converted to 2009 dollars using the Bureau of Labor Statistics Inflation Calculator. To determine EITC values, children include a family's own children and other, identifiable related children in the family who are under 18 years of age or 18 to 23 years old and attending school full time, and own disabled children regardless of age. IRS data and some tax models find more EITC claimants than are found using Census data such as the CPS. Some of the information missed by CPS includes estimates of nonresident children and details about who claims each child. CPS estimates (not shown) of the total EITC value are much lower than sources relying on tax models, IRS data, or Office of Management and Budget (OMB) projections. Note that it is also possible that the CPS underestimates the dollar value of the total increase in the EITC. All analyses are weighted to adjust for sampling.

\section{A B OUT THE AUTHOR}

Beth Mattingly is a family demographer at the Carsey Institute.(beth.mattingly@unh.edu)

\section{A C K N O W L E D G M E N T S}

The author thanks Arloc Sherman at the Center for Budget and Policy Priorities, Elizabeth Kneebone at the Brookings Institution, Reagan Baughman at the University of New Hampshire, Kristin Smith and Anne Shattuck at the Carsey Institute, and Amy Battjer and Debbie Stein at the Hatcher Group for their feedback in preparing this brief.

\section{Endnotes}

${ }^{1}$ Estimates from the 2005-2007 American Community Survey using the Amercian FactFinder tool at www.census. gov.

${ }^{2}$ Estimates based on author's analyses of March 2008 Current Population Survey data, as discussed in the data section.

${ }^{3}$ See Holt, Steve. 2006. "The Earned Income Tax Credit at Age 30: What We Know.” Washington, DC: The Brookings Institution (February).

${ }^{4}$ Holt, Steve. 2006. "The Earned Income Tax Credit at Age 30: What We Know." Washington, DC: Brookings Institution (February). See also: Berlin, Gordon. 2009. "Transforming the EITC to Reduce Poverty and Inequality." Pathways (Winter): 28-32.

${ }^{5}$ Center on Budget and Policy Priorities. 2008. "Policy Basics: The Earned Income Tax Credit." Washington, DC (December 17), http://www.cbpp.org/files/policybasics-eitc. pdf, accessed April 9, 2009.

${ }^{6}$ For a review of the EITC effects, see Berube, Alan, David Park, and Elizabeth Kneebone. 2008. "Metro Raise: Boosting the Earned Income Tax Credit to Help Metropolitan Workers and Families." Washington, DC: Brookings Institution (June). See also, for example: Grogger, Jeffrey. 2003. "The Effects of Time Limits, the EITC, and Other Policy Changes on Welfare Use, Work, and Income Among Female-Headed Families." The Review of Economics and Statistics 85(2): 395-408, http://www.soc.washington.edu/ users/brines/grogger.pdf, accessed April 3, 2009; Ellwood, David T. 2000. "The Impact of the Earned Income Tax Credit and Social Policy Reforms on Work, Marriage and Living Arrangements." National Tax Journal 53: 1063-1105; Neumark D, and W. Wascher. 2001. "Using the EITC to Help Poor Families: New Evidence and a Comparison with the Minimum Wage." National Tax Journal 54(2): 281-317. For discussion of labor force participation, see also Berube, 
Alan. 2007. "The Importance of the EITC to Urban Economies." Washington, DC: Brookings Institution, http:// www.brookings.edu/ /media/Files/rc/speeches/2007/071 3childrenfamilies_berube/20070713_berube.pdf, accessed April 13, 2009.

${ }^{7}$ See: Berube, Alan, David Park, and Elizabeth Kneebone. 2008. "Metro Raise: Boosting the Earned Income Tax Credit to Help Metropolitan Workers and Families." Washington, DC: Brookings Institution (June).

${ }^{8}$ See: Berube, Alan, David Park, and Elizabeth Kneebone. 2008. "Metro Raise: Boosting the Earned Income Tax Credit to Help Metropolitan Workers and Families." Washington, DC: Brookings Institution (June), 19.

${ }^{9}$ This penalty is considered at the couple level. If an unmarried woman who does not work married a low-earning man, she may newly qualify for the EITC and the credit amount may go up because of their marital status. Thus, for such couples, there is a small marriage subsidy.

${ }^{10}$ See Tax Policy Center. 2008. "Earned Income Tax Credit Parameters, 1975-2009.” Washington, DC (November 5), http://www.taxpolicycenter.org/taxfacts/Content/PDF/ historical_eitc_parameters.pdf, accessed March 31, 2009; Internal Revenue Service. 2009. "EITC Thresholds and Tax Law Updates.” Washington, DC (February 11), http://www. irs.gov/individuals/article/0,,id=150513,00.html, accessed March 31, 2009; Internal Revenue Service. "Earned Income Credit (EIC)." Publication 596 http://www.irs.gov/pub/irspdf/p596.pdf, accessed March 31, 2009.

${ }^{11}$ See The American Recovery and Reinvestment Act of 2009-February 12, 2009. Full Summary of Provisions from Senate Finance, House Ways \& Means Committees, http://finance.senate.gov/press/Bpress/2009press/ prb021209.pdf, accessed March 31, 2009. See Also UrbanBrookings Tax Policy Center. 2009. "Tax Proposals in the 2010 Budget.” Washington, DC, http://www.taxpolicycenter.org/UploadedPDF/411849_2010_budget.pdf accessed April 3, 2009.

${ }^{12}$ The phase-in rate for families with three or more children was raised from 40 percent (when the rate was the same as that for two child families) to 45 percent of earned income (thus raising the maximum credit from $\$ 5,028$ to $\$ 5,657$ for these families). This increases the dollar amount of the EITC for large working families. This group is represented by the largest shaded area on Figure 1 .

${ }^{13}$ The threshold for married couples was increased to $\$ 5,000$ (from $\$ 3,120$ ) above the amount for unmarried filers. This both expands eligibility and, for some, increases the credit. The phase-out threshold amount for married couples is indexed to inflation after 2009. This change is shown by the red dashed lines on Figure 1.
${ }^{14}$ These changes affect the income levels at which filers become ineligible for the EITC. There were no changes for unmarried filers with fewer than three children; however, unmarried filers with three or more children are eligible until earnings reach $\$ 43,281$. For all married couples, there is an expanded range of eligibility. Those with no children can claim an EITC if their earnings are below $\$ 18,444$; married couples with one or two children are eligible for the EITC if their combined earnings are less than $\$ 40,463$ for one child or $\$ 45,295$ for two children. Married filers with three or more children are EITC eligible when earnings are under $\$ 48,281$. These values are well above the poverty line ( $\$ 25,694$ in 2008 for a married couple with three children), thus the federal EITC benefits those in the lowmiddle class as well as poor families (See U.S. Bureau of the Census. "Poverty Thresholds for 2008 by Size of Family and Number of Related Children Under 18 Years," http://www. census.gov/hhes/www/poverty/threshld/thresh08.html, accessed April 14, 2009).

${ }^{15}$ See Aron-Dine, Aviva, and Arloc Sherman. 2007. "Ways and Means Committee Chairman Charles Rangel's Proposed Expansion of the EITC for Childless Workers: An Important Step to Make Work Pay." Washington, DC: Center on Budget and Policy Priorities (October 25, 2007), http://www.cbpp.org/files/10-25-07tax.pdf, accessed March 25, 2009. For a state-by-state breakdown, see Kneebone, Elizabeth. 2009. "Economic Recovery and the EITC: Expanding the Earned Income Tax Credit to Benefit Families and Places." Washington, DC: Brookings Institution. http://www.brookings.edu/ /media/Files/rc/ papers/2009/0129_eitc_kneebone/20090126_eitc_kneebone.pdf, accessed March 26, 2009.

${ }^{16}$ See The Brookings Institution. 2008. "The Scouting Report: Decrease Poverty and Increase Opportunity." November 26, 2008 Interview with Rebecca Blank, http://www. brookings.edu/events/2008/1126_poverty_chat_transition. aspx, accessed March 18, 2009; Berube, Alan, David Park, and Elizabeth Kneebone. 2008. "Metro Raise: Boosting the Earned Income Tax Credit to Help Metropolitan Workers and Families." Washington, DC: Brookings Institution (June).

${ }^{17}$ Berube, Alan, David Park, and Elizabeth Kneebone. 2008. "Metro Raise: Boosting the Earned Income Tax Credit to Help Metropolitan Workers and Families." Washington, DC: Brookings Institution (June).

${ }^{18}$ See Aron-Dine, Aviva, and Arloc Sherman. 2007. "Ways and Means Committee Chairman Charles Rangel's Proposed Expansion of the EITC for Childless Workers: An Important Step to Make Work Pay." Washington, DC: Center on Budget and Policy Priorities (October 25, 2007), http://www.cbpp.org/files/10-25-07tax.pdf, accessed March 25, 2009. See also: Center for Law and Social Policy. 2008. 
"CLASP Federal Policy Recommendations for 2009 and Beyond: An Overview." (October 16) Washington, DC, http:// www.clasp.org/publications/clasp__fedpolicyrecommendationsfor2009andbeyond.pdf, accessed March 27, 2009; Berube, Alan, David Park, and Elizabeth Kneebone. 2008. "Metro Raise: Boosting the Earned Income Tax Credit to Help Metropolitan Workers and Families." Washington, DC: Brookings Institution (June); and Economic Policy Institute. 2008. EPI Policy Handbook: A Plan to Revive the American Economy (August 8), Washington, DC, https://secure.epi.org/publications/entry/plan_to_revive_the_american_economy/, accessed March 27, 2009.
${ }^{19}$ Berlin, Gordon. 2009. "Transforming the EITC to Reduce Poverty and Inequality.” Pathways (Winter): 28-32.

${ }^{20}$ Center for American Progress. 2007. "From Poverty to Prosperity: A National Strategy to Cut Poverty in Half." Washington, DC (April, 2007), http://www.americanprogress.org/issues/2007/04/pdf/poverty_report.pdf, accessed March 25, 2009; Berube, Alan, David Park, and Elizabeth Kneebone. 2008. "Metro Raise: Boosting the Earned Income Tax Credit to Help Metropolitan Workers and Families." Washington, DC: Policy Program, Brookings Institution (June).

\section{CARSEY}

Building knowledge for families and communities

The Carsey Institute conducts policy research on vulnerable children, youth, and families and sustainable community development. We give policymakers and practitioners timely, independent resources to effect change in their communities.

The Carsey Institute is supported by the Annie E. Casey Foundation's initiative to strengthen rural families and by the W.K. Kellogg Foundation.

Huddleston Hall

73 Main Street

Durham, NH 03824

(603) 862-2821

www.carseyinstitute.unh.edu 